\title{
Collaborating against COVID-19: bridging travel and travel tech
}

\author{
Isaac Mizrachi ${ }^{1,2}$ (D) Ulrike Gretzel ${ }^{1,2}$
}

Received: 27 August 2020 / Revised: 22 October 2020 / Accepted: 5 November 2020 /

Published online: 16 November 2020

(C) Springer-Verlag GmbH Germany, part of Springer Nature 2020

\begin{abstract}
The distinction between "traditional" travel businesses and travel tech companies has remained steady for years due to knowledge, resource and financial reasons, leading them to operate in separate bubbles. The massive damages caused by COVID-19 for both sides of the industry pose a unique opportunity for them to ditch the old transactional working model, and to seek for more strategic collaborations in order to weather the storm. This viewpoint article discusses the business potential behind such collaborations in the short and long runs-from improving immediate safety perceptions to building technological foundations for the travel industry of tomorrow. It argues that local government mediation is needed for it to succeed, in formats such as funded hackathons or incubation programs that are targeted at addressing COVID-19 and its unique challenges.
\end{abstract}

Keywords Travel tech $\cdot$ Travel startups $\cdot$ Travel safety perceptions $\cdot$ Destination marketing $\cdot$ COVID-19

\section{Introduction: two bubbles serving one industry}

For years, the "traditional" travel industry and the travel tech sector have worked side by side, each in its own bubble. A visit to any major travel trade show, from WTM in London to ITB in Berlin reveals this separation: specific halls are designated for hotels, travel agents, airlines and so on, while the travel tech part gets a different exhibition space-or even a separate conference, such as Travel Forward

Isaac Mizrachi

ismizrachi@gmail.com

Ulrike Gretzel

gretzel@usc.edu

1 Department of Hotel and Tourism Management, Ben Gurion University of the Negev, Be'er Sheva, Israel

2 USC Center for Public Relations, Annenberg School of Communication and Journalism, University of Southern California, Los Angeles, CA, USA 
that takes place alongside WTM but requires buying another entry ticket (https ://travelforward.wtm.com/). This distinction between "travel" and "travel tech" puts hoteliers, restaurateurs and National Tourist Organization (NTO) leaders on one side, with data scientists, developers and tech entrepreneurs on the other. The two only get together to solve specific problems-but even then, collaboration is minimal and the relationships are of a client and a service provider in a typical transactional model.

Some might argue that these two sectors are just too different to work more in sync. The "traditional" travel industry, with its often fragmented nature, is massive in its scope. It spans across various segments, ranging from big hierarchically structured players to one-person enterprises. Despite this diversity, it is very common to see strategic collaborations between the sectors, such as airlines negotiating new routes with NTOs, or hotels running marketing alliances with local destination marketing organizations (DMOs) in an effort to increase visitation and to build a more holistic destination image (Wang and Xiang 2007). As a result, it is also quite common to see manpower exchange between the sectors, where a top hotelier can potentially find themselves leading a tour company or heading a DMO, for instance. As to finance, it is safe to assume that many entities under the "traditional" travel umbrella are enjoying some public support (for example, the "subvention"- - a subsidy to attract convention organizers, or government subsidies to attract airlines to land at a destination). This is due to the strong link the industry has with politics. In fact, many DMOs and airlines are actually government organizations, which further illustrates the clear link to public funding. Last but not least, "traditional" travel entities are in many cases real estate businesses that are owned or heavily financed by banks. With regards to finance it is also important to mention that many travel businesses (especially the smaller ones) are traditionally managed by families. While some strive for big revenues and aim for constant return on investment, others are micro entrepreneurs that chose tourism as a lifestyle rather than a money-making machine (Peters and Kallmuenzer 2018; Komppula 2004; Bastakis et al. 2004).

The travel tech sector, on the other hand, is more fluid in its structure and does not possess a single definition. Some might argue that it is the cluster name for all technology startup companies that offer a product aimed at the "traditional" tourism industry (for instance, a guest communication platform for hoteliers), while others use this term to group all the technology companies that serve the travel industryfrom online travel agencies (OTAs) to property management systems. In this article, the focus is on the former: travel tech as a sector of entrepreneurs working on digital products in order to simplify the travel experience and/or tackle challenges that the "traditional" industry is facing, from payment to marketing and so on. These entrepreneurs usually emerge from different backgrounds-many have never worked in tourism before. They tend to have a strong exit motivation that guides them, which is the process that leads to their departure from the company they created (DeTienne 2010). Till that moment arrives, they are busy financing the development of their company in various ways, from relying on their personal savings (bootstrapping) to seeking venture capital from investors. Some early-stage startups enjoy government funding through unique incubation programs. Generally speaking, travel tech startups are launched worldwide, with most investments taking place in the U.S., 
followed by India and China (https://tinyurl.com/yybnbqu2). Therefore, our discussion is not limited to a specific geographic region.

There is not a single answer as to why these two sectors usually avoid strategic collaborations and stick with sporadic, transactional relationships (or even single market transactions) instead. Some assumptions for that include the following:

- Travel tech entrepreneurs focus on getting venture capital to finance their business, and will therefore develop products that can be sold faster and at scale. Ongoing collaborations with business entities that do not offer them capital and/ or technological resources might slow them down and divert them from their original growth goals.

- "Traditional" tourism executives often focus on short-term sales targets that are determined by market demand and supply, as well as in response to unpredictable factors as the weather, geo-political issues and so on. This reality takes most of the time and effort they could have spent working on strategic, long-term goals with tech partners.

- People who work in travel tech startups do not necessarily understand the travel landscape: they can be developers or data scientists that have never worked a day in tourism. By the same token, people who work in "traditional" tourism do not necessarily possess any technical know-how. In many cases, limited resources and lack of training lead to mediocre digital adoption by travel entities (Mistilis and Gretzel 2013). It is almost like the two sides speak a different language.

\section{The catastrophe and the opportunity: no one is immune against COVID-19}

The outbreak of COVID-19 in December 2019 and its devastating impact globally in the months to follow have brought tourism and its related industries down to their knees. As of July 2020, the UNWTO predicts a decline of 58\%-78\% in international tourist arrivals down from an estimated growth of 3\% to $4 \%$ forecast in early January 2020 (https://www.unwto.org/tourism-covid-19). Lockdowns, border closures and fear from an unknown virus have made millions worldwide ditch their travel plans for 2020, leaving 100-120 million direct tourism jobs at risk. COVID-19 has left its mark on the travel tech sector as well with immediate actions taken to deal with the crisis, from ruling a hiring freeze to laying off large numbers of employees worldwide (https://www.bbc.com/news/technology-52091615). These steps will most likely change the breadth of the sector and will slow down its rapid growth of recent years. As part of that, many early stage startups might not survive the crisis due to lack of available funding options, as well as paying clients that are currently busy surviving.

As a vaccine cannot be anticipated in the near future (https://tinyurl.com/y6qh9 $7 x f$ ), the industry has to develop immediate recovery plans to allow at least a partial operation alongside the virus, as well as long term strategies for an improved visitor economy. A solid collaboration between the travel and travel tech sectors may help them both weather the storm. To enable this collaboration, local tourism authorities 
(NTOs, DMOs and economic development city units) should act as mediators between the two and help to bridge the gaps. This mediation can take place in various ways, from running brainstorming sessions where participants discuss their current needs while others try to address them, to funding special joint incubation or hackathon programs that are focused on COVID-19. Without such mediation, it might be difficult for the two sides to see the macro picture that is beyond their quick, personal survival needs. Once all parties sit together around the same table, it would be easier to exploit the current opportunities: the short-term and the less immediate future ones. In particular, two root causes that need to be addressed and potentially mediated by local tourism authorities in order to bridge the gaps are education and finance.

Education: There is minimal exposure to travel tech and startup culture in tourism education, from high school to university (Fuchs and Höpken 2020). A quick look at a typical syllabus of an average BA degree in Hospitality Management would most likely reveal no units on tech entrepreneurship in travel, not to mention something a bit more advanced as coding or UX design. The exposure problem starts there, and intensifies at the workforce-where the time and resources needed to learn something new are limited given the financial targets. At the same time, travel tech entrepreneurs with an MBA or a Computer Science degree might find it difficult to obtain exposure to basic principles in tourism education. An optional solution would be for local NTOs to develop and run short certificate programs for each sector to enrich their knowledge and eliminate any tech/tourism phobias they might have: an introductory program in travel tech for those who work in the "traditional" part of the industry, and a tourism foundations program for tech entrepreneurs.

Finance: There seem to be limited joint ventures between the sectors, such as tourism-focused incubators or hackathons that invite hoteliers, for example, to pitch for ideas based on current needs, and for tech entrepreneurs to work with them on product development. At the moment, the hotelier is busy making more money to pay their heavy leasing agreements, while the tech entrepreneur is occupied in calls and meetings with potential investors. NTOs should jump in and create a financial framework that would allow travel businesses and tech entrepreneurs to work together without having to neglect their different business priorities. Some destination authorities are already offering such frameworks, such as the Tourism Startup Cooperation Project that was initiated by the Seoul Metropolitan Government (Gretzel et al. 2018).

Addressing both Education and Finance issues as mentioned above would help the two sides to merge and tackle two major challenges: first, the immediate, shortrun goal of improving travel safety perceptions in the age of COVID-19 and allowing travel to restart. Second, the long-run goal of co-building stronger technological foundations for the travel industry of tomorrow. 


\section{Winning together in the short-run: Improving travel safety perceptions}

As the number of new COVID-19 cases began to fall, countries around the world have started to ease some lockdown regulations in order to revive struggling economies. This is particularly evident in Europe, where countries such as Cyprus and Greece have already launched "open for tourists" campaigns and the EU published a list of nationalities that are allowed to enter Europe (https://tinyurl.com/y9x2v6b5). Despite that, demand is still low due to safety perceptions that potential visitors have, leaving planes, hotels and restaurants across the continent empty (https://tinyurl.com/y6rb2qtb). The perceived health risk from COVID-19 is a new addition to the long list of tourist risks, which vary from financial and cultural risks to risks associated with natural disasters and terrorism (Arana and León 2008; Chew and Jahari 2014; Fuchs and Reichel 2006; Jonas et al. 2011; Roehl and Fesenmaier 1992). These perceived risks might influence tourists' decision making and lead them to cancel or postpone a trip, or change the destination in an effort to reduce the perceived risks to a tolerable level, enabling them to go ahead with their travel plans (Fuchs and Reichel 2011). For tourism and hospitality businesses, it means one main thing: product and service preparedness, in an effort to reduce visitors' safety and risk perceptions associated with COVID-19. Sales-focused marketing is less relevant right now, as there is little demand to capture. Instead, people need to know that it is safe to travel. Technology can help to mediate that.

A basic classification of "COVID-19 ready" short-term technology needs by the travel industry may include the following:

- Hygiene: How can tourism businesses ensure that hygiene and cleanliness quality of their venue are of the highest standards? The need here is for technological solutions that can have a positive impact on hygiene quality. For instance, museum audio guide physical devices can be replaced by apps, so that visitors could enjoy the same content on their smartphones without health concerns.

- Traffic control: People congestion is a big challenge when it comes to COVID-19. For tourism businesses, that can be a real headache-from check in procedures to guests using public facilities inside the venues. The need here is for digital tools that can monitor in-venue traffic, as well as booking tools to allow greater control over facilities usage.

- Immediate communications: Crisis management requires constant communication. Hospitality consumers, from theme parks visitors to hotel guests, may feel more confident when being updated regularly about venue regulations, steps being taken to ensure guest safety and so on. For that, simple Facebook updates in a noisy, advertising-led environment may not be sufficient. 


\section{Winning together in the long-run: building the technological foundations for the travel industry of tomorrow}

It may seem like a thing of the past, but only a few months back governments and travel destinations worldwide have struggled with the negative impact of the visitor economy. Overtourism in cities like Amsterdam, Venice and Barcelona forced locals to abandon the historic city centers (Dodds and Butler 2019; Milano et al. 2019); visitors were banned from island destinations like Faroe Islands and Boracay in an effort to protect their unique environment (https://tinyurl.com/ yy36c6f5); and of course, the industry's contribution to global greenhouse emissions, one of the major causes of global warming (Lenzen et al. 2018). The global spread of COVID-19 stopped these issues at once, with empty streets, hotel closures and grounded airplanes. There are reports on improved air quality in once polluted destinations like Beijing and Mumbai, which bring to mind thoughts on a potential new tourism industry, one that truly respects the environment. With markets opening up, first reports of a potential comeback of overtourism in the UK and China have arrived (https://tinyurl.com/vv8tyo2), which only stress the need for an immediate action.

If the spread of COVID-19 has any positive sides, one would be the opportunity to build the technological foundations for the travel industry of the postCOVID era. The industry was given a once in a lifetime moment to start again, an opportunity to re-think tourism in general and IT in tourism in particular (Gretzel et al. 2020). Here too, the two travel bubbles should work together strategically to ensure this unique opportunity is not wasted.

One such major challenge to address is traffic control in overcrowded destinations. Should busy old towns implement a time-allotment system to avoid visitor congestion? Imagine tourists leaving their cruise ship in Venice, all wearing a digital bracelet that is connected to their profile with the cruise company. That bracelet starts beeping once the $120 \mathrm{~min}$ (or so) of their allowed visit duration is about to finish. Those who will not comply and keep strolling will be fined automatically, with funds going back to the local DMO for development projects. The same bracelet can also monitor which areas in town tourists can go to, to help locals maintain their quality of life standards. For example, some streets may be banned for visitors between certain hours, or during specific days such as public holidays. Here too, unauthorized visits by tourists will be tracked by the system and lead to fines. This is already implemented now for enforcing COVID-19 related quarantine requirements imposed on travelers at destinations such as Abu Dhabi (https://tinyurl.com/y2wr7xco).

Of course, there are privacy concerns associated with such a system (Tussyadiah et al. 2019; Anuar and Gretzel 2011). No one likes to be followed by local authorities. At the same time, such a system is not very hospitable and welcoming for visitors. Having said that, one needs to consider its clear weaknesses versus the benefits it may offer in the important fields of sustainability and destination management.

Another challenge that travel tech can address is the profiling of prospective visitors to a destination. This is a sensitive topic, yet some DMOs have previously 
expressed their interest in attracting "the right" kind of audiences and avoid others. They claimed that their suggestion was purely about matching the right product to the right consumer and had nothing to do with discrimination. If indeed this approach becomes a norm in the post COVID-19 world, then big data tools can assist DMOs with exactly that. Advanced chatbots are already in use in travel, providing visitors useful information while learning about their personal travel habits and style. Backend AI systems could analyse big data to help travel authorities build better products and improved marketing plans.

These suggestions are not just about technology implementation: they require technology integration, which can only come to fruition in a holistic thinking process that involve both "traditional" travel and travel tech practitioners.

\section{Summary}

If there is a bright side for COVID-19 when it comes to the tourism industry, it probably is the call to action it gives to both "travel" and "travel tech" decision makers worldwide to join forces and weather the storm together. For years, they have worked in separate bubbles, for various reasons. The main two root causes that need to be addressed and potentially mediated by local tourism authorities in order to bridge the gaps are education and finance.

Education: "Classic" tourism and hospitality education usually omits any reference to travel tech and the startup culture in general, while travel tech entrepreneurs usually lack any background in tourism. The mutual exposure problem starts in the classroom, and leads to the lack of collaboration later on.

Finance: Each side is busy obtaining the funds they need to survive- the hotelier needs to pay rent and payroll, while the entrepreneur needs to hire a new product manager or buy new software to beat the competition in the brutal race to market. With the lack of a joint venture between the two that may help them to reach their financial goals together, their attention remains limited to their own backyard.

Decision makers in the global travel business understand today that in order to survive the pre-vaccine period, they need to adapt to a new travel landscape dictated by COVID-19. Merging the "tech" and the "traditional" travel bubbles through mediation by local or national destination authorities could be one big step ahead that would make the industry stronger and healthier.

\section{References}

Anuar F, Gretzel U (2011) Privacy concerns in the context of location-based services for tourism. In ENTER 2011 Conference, Innsbruck, Austria, January 26-28, 2011. http://ertr.tamu.edu/enter -2011-short-papers/

Arana JE, León CJ (2008) The impact of terrorism on tourism demand. Ann Tour Res 35(2):299-315

Bastakis C, Buhalis D, Butler R (2004) The perception of small and medium sized tourism accommodation providers on the impacts of the tour operators' power in Eastern Mediterranean. Tour Manag 25(2):151-170 
Chew EYT, Jahari SA (2014) Destination image as a mediator between perceived risks and revisit intention: a case of post-disaster Japan. Tour Manag 40:382-393

DeTienne DR (2010) Entrepreneurial exit as a critical component of the entrepreneurial process: theoretical development. J Bus Ventur 25(2):203-215

Dodds R, Butler R (eds) (2019) Overtourism: issues, realities and solutions, vol 1. Walter de Gruyter $\mathrm{GmbH} \& \mathrm{Co} \mathrm{KG}$, Berlin

Fuchs M, Höpken W (2020) E-tourism curriculum. In: Handbook of e-tourism, pp 1-26

Fuchs G, Reichel A (2006) Tourist destination risk perception: the case of Israel. J Hosp Leisure Mark 14(2):83e108

Fuchs G, Reichel A (2011) An exploratory inquiry into destination risk perceptions and risk reduction strategies of first time vs. repeat visitors to a highly volatile destination. Tour Manag 32(2):266-276

Gretzel U, Ham J, Koo C (2018) Creating the city destination of the future-the case of smart Seoul. In: Wang Y, Shakeela A, Kwek A, Khoo-Lattimore C (eds) Managing asian destinations. Springer, Berlin (Forthcoming)

Gretzel U, Fuchs M, Baggio R, Hoepken W, Law R, Neidhardt J, Pesonen J, Zanker M, Xiang Z (2020). e-Tourism beyond COVID-19: a call for transformative research. Inf Technol Tour. https://doi. org/10.1007/s40558-020-00181-3

Jonas A, Mansfeld Y, Paz S, Potasman I (2011) Determinants of health risk perception among low-risktaking tourists traveling to developing countries. J Travel Res 50(1):87-99

Komppula R (2004) Success and growth in rural tourism micro-businesses in Finland: Financial or lifestyle objectives?. In: Thomas R (ed) Small firms in tourism: international perspectives, Elsevier Science B.V, Amsterdam, pp 115-138

Lenzen M, Sun YY, Faturay F, Ting YP, Geschke A, Malik A (2018) The carbon footprint of global tourism. Nat Clim Change 8(6):522-528

Milano C, Cheer JM, Novelli M (eds) (2019) Overtourism: excesses, discontents and measures in travel and tourism. CABI, Wallingford

Mistilis N, Gretzel U (2013) Tourism operators' digital uptake benchmark survey 2013. Retrieved from http://www.tra.gov.au/documents/Tourism_Operators_Survey.pdf. Accessed 1 July 2020

Peters M, Kallmuenzer A (2018) Entrepreneurial orientation in family firms: the case of the hospitality industry. Curr Issues Tour 21(1):21-40

Roehl WS, Fesenmaier DR (1992) Risk perceptions and pleasure travel: an exploratory analysis. J Travel Res 30(4):17-26

Tussyadiah I, Li S, Miller G (2019) Privacy protection in tourism: where we are and where we should be heading for. In: Information and communication technologies in tourism 2019. Springer, Cham, pp 278-290

Wang Y, Xiang Z (2007) Toward a theoretical framework of collaborative destination marketing. J Travel Res 46(1):75-85

Publisher's Note Springer Nature remains neutral with regard to jurisdictional claims in published maps and institutional affiliations. 